\title{
A CLINICAL AND BIOCHEMICAL APPROACH TO CHOLINESTERASE PROBLEMS IN ANAESTHESIA
}

\author{
A. M. LeACOCK, M.D.C.M., D. J. CAMPBELL, PH.D., AND \\ J. W. R. MCINTYRE, F.F.A.R.C.S."
}

THE ENZYME CHOLINESTERASE was demonstrated in human serum by Vahlquist in 1935, and five years later Alles and Hawes showed that a cholinesterase existed in red blood corpuscles, this latter differing qualitatively from serum cholinesterase. Both these enzymes have several synonyms, red cell cholinesterase being referred to alternatively as true, acetyl-, "C" type, or specific cholinesterase. Similarly serum cholinesterase may be called pseudo-, butyro- (butyryl), or nonspecific cholinesterase. In this paper the terms true, and pseudo-, cholinesterase will be used. ${ }^{2}$

True cholinesterase is widely distributed throughout the nervous system, and is highly concentrated at the motor end plates, where it is responsible for inactivating the transmitter acetylcholine. The mechanisms involved in this enzyme substrate reaction have recently been reviewed by Kitz. ${ }^{2}$

Although there is abundant evidence that pseudocholinesterase is synthesized in the liver, ${ }^{3}$ the physiological role of the enzyme is unknown, and its total absence is compatible with life. Doenicke, Gurtner, and others reported a case of prolonged apnoea in a 76-year-old woman following the administration of succinylcholine. ${ }^{4}$ Subsequent blood investigation showed pseudocholinesterase to be absent, yet the patient had been healthy until administration of the succinylcholine. Similar cases have been reported by Liddell ${ }^{5}$ and Motulsky. ${ }^{6}$ However, the enzyme plays an important part in the hydrolysis of two types of drug: (1) succinylesters of choline such as succinylcholine, and (2) esters of benzoic acid such as procaine and amethocaine. Thus the enzyme has a certain pharmacological if not physiological significance, and it became of particular interest when succinylcholine became widely used. Reports occurred of incidents in which the apparent duration of activity of succinylcholine was unexpectedly long, and though in some cases this could be correlated with subnormal pseudocholinesterase levels, it soon became clear that an explanation other than that of a quantitative deficiency was also necessary. ${ }^{7-10}$ It was suggested that there were forms of the enzyme with varying activity, and that the presence of these might be genetically dependent. ${ }^{11}$ It is the purpose of this paper to consider briefly the present knowledge of inherited abnormalities in pseudocholinesterase, present case reports, and discuss the management of these patients.

The abnormal or atypical enzyme differs from the usual type in two ways: (1) It is less active in hydrolysing a large number of substrates including

-Departments of Anaesthesia and Clinical Laboratory Services, University of Alberta Hospital, Edmonton, Alberta.

Can. Anaes. Soc. J., vol. 13, no. 6, November, 1966 
succinylcholine. (2) It is more resistant to the majority of cholinesterase inhibitors than the normal enzyme, or its activity is less affected by dibucaine.

The difference in inhibitor sensitivity led to the development of the dibucaine number by Kalow and Genest in 1957,12 and of fluoride numbers by Harris and Whittaker in $1961 .^{18}$ In the Kalow and Genest test, normal sera lose 80 per cent of their activity in the presence of dibucaine (or nupercaine, which is a prostigmine analogue), while pseudocholinesterase from patients with the atypical gene is inhibited by only 20 per cent.

On the basis of dibucaine numbers, Kalow and Staron ${ }^{14}$ were able to divide the population into three groups:

$\begin{array}{ccc}\text { D.N. } & \text { Genetically } & \text { Distribution (\%) } \\ 80 & \begin{array}{c}\text { Normal } \\ \text { homozygous }\end{array} & 97 \\ 62 & \begin{array}{c}\text { Heterozygotes } \\ \text { Atypical }\end{array} & 3 \\ 20 & \text { homozygotes } & 0.03 \text { or } 1: 3000\end{array}$

Kalow based his recorded incidence on the distribution found in the Canadian population. This incidence has been duplicated in studies of other population groups.

Again it was found that all clinical cases could not be fitted into the dibucaine number pattern. When fluoride was used as the inhibitor instead of dibucaine, family studies indicated the occurrence of another inheritable type of pseudocholinesterase. In addition, there are the families with absent pseudocholinesterase activity investigated by Doenicke, ${ }^{4}$ Liddell, ${ }^{5}$ and Motulsky, ${ }^{6}$ and a silent gene appears to be the explanation for these cases.

Thus it now seems evident that there are four allelic genes which control the inheritance of pseudocholinesterase. There is the gene producing normal pseudocholinesterase, which has been designated $E_{1}{ }^{u}$. Three allelic mutants $E_{1}{ }^{a}, E_{1}{ }^{t}$ and $\mathrm{E}_{1}{ }^{8}$ are responsible for the abnormal dibucaine, fluoride, and silent types of pseudocholinesterase.

Table I tabulates the known normal and abnormal phenotypes of the pseudocholinesterase system that must result from the acceptance of the hypothesis that four allelic mutants of pseudocholinesterase exist in a world population. ${ }^{6}$ The $E_{1}{ }^{p}$ $\mathrm{E}_{1}{ }^{8}$ genotype has not yet been clinically observed.

Consideration will now be given to some of the factors involved in treatment of succinylcholine apnoea. There are, of course numerous reasons for postoperative apnoea, and it is essential to decide initially if the apnoea is of peripheral or central origin, ${ }^{15}$ and, if peripheral, whether or not succinylcholine is the aetiological factor. No attempt will be made here to discuss the differential diagnosis or to outline complete therapy; however some of the significant factors will be reviewed. Churchill-Davidson and others have stressed repeatedly that the cornerstone of successful treatment of prolonged apnoea is good ventilation.15-18 Even in a patient with no pseudocholinesterase, reversal of succinylcholine activity 
TABLE I

Incidence and Distribution of Hereditary Pseudocholinesterase Variants*

\begin{tabular}{|c|c|c|c|c|c|c|}
\hline Genotype & Phenotype & Incidence & Enzyme & $\begin{array}{l}\text { Succinyl- } \\
\text { choline } \\
\text { response }\end{array}$ & $\begin{array}{c}\text { D.N. } \\
\text { (normal 80) }\end{array}$ & $\underset{\text { (normal 60) }}{\text { F.N. }}$ \\
\hline 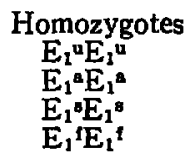 & $\begin{array}{l}\mathrm{U} \\
\mathrm{A} \\
\mathrm{S} \\
\mathrm{F}\end{array}$ & $\begin{array}{l}1: 1 \\
1: 2500 \\
1: 100,000 \\
\text { very rare }\end{array}$ & $\begin{array}{l}\text { normal } \\
\text { atypical } \\
\text { no activity }\end{array}$ & $\begin{array}{c}\mathbf{N} \\
+++ \\
+++ \\
++\end{array}$ & $\begin{array}{l}80 \\
20 \\
70\end{array}$ & $\begin{array}{l}60 \\
20 \\
30\end{array}$ \\
\hline $\begin{array}{l}\text { Heterozygote } \\
\qquad E_{1^{1}} \mathrm{E}_{1^{a}}\end{array}$ & es & $1: 25$ & mixture of & + & 60 & 45 \\
\hline$E_{1}{ }^{u} E_{1}^{t}$ & UF & - & $\begin{array}{c}\text { mixture of } \\
\text { enzymes }\end{array}$ & + & 75 & 50 \\
\hline$E_{1}{ }^{n} E_{1}{ }^{f}$ & IF & - & $\begin{array}{c}\text { mixture of } \\
\text { enzymes }\end{array}$ & ++ & 45 & 35 \\
\hline$E_{1}{ }^{n} E_{1}{ }^{s}$ & $\mathrm{U}$ & $1: 200$ & $\begin{array}{l}\text { usual type } \\
\text { decreased } \\
\text { activity }\end{array}$ & + & 80 & 60 \\
\hline$E_{1} \mathrm{E}_{1}$ & A & $1: 8000$ & $\begin{array}{l}\text { a typical } \\
\text { esterase } \\
\text { decreased } \\
\text { activity }\end{array}$ & ++++ & 20 & 20 \\
\hline$E_{1} E_{1}$ & $\mathbf{F}$ & - & not observed & - & - & 一 \\
\hline
\end{tabular}

"Based upon observations and calculations by Kalow, Motulsky, and others.

will eventually occur-through the process of non-enzymatic hydrolysis. ${ }^{15}$ Kalow has estimated that less than 5 per cent of the succinylcholine which is in the mammalian body at any given time will be destroyed per hour by alkaline hydrolysis in the presence of physiological levels of $\mathrm{pH}$ and $\mathrm{P}_{\mathrm{CO}_{2}}{ }^{19}$ Thus good ventilation is essential to non-enzymatic hydrolysis. The first point in therapy then would be to continue to ventilate-and to obtain arterial blood for blood gas studies when this is possible, and to correct respiratory or metabolic acidosis if it is present.

The second consideration is the use of the anticholinesterase drugs, neostigmine and edrophonium. The anticholinesterase drugs act as succinylcholine extenders when given to normal individuals. The same thing may happen in the individual with atypical pseudocholinesterase-that is, the administration of neostigmine may (and probably did in three of our patients) only serve to prolong the block. On the other hand it is also evident that the neostigmine may act to reverse the block, just as it does with d-tubocurare and gallamine.

The partial explanation of this ambiguous action of the anticholinesterases is that when succinylcholine is present for a long time-as it is in the atypical pseudocholinesterase deficiencies-or when it is given in large doses over a prolonged period, the end-plate region undergoes a change and the initial depolarizing block evolves into a non-depolarizing block. ${ }^{20}$ The difficulty from a clinical standpoint is in knowing when the depolarizing block has progressed to a non-depolarizing or dual type of block.21

It is here that the nerve stimulator may be of help. If the presence of both fade and post-tetanic facilitation is demonstrated, this is confirmatory evidence of 
non-depolarizing block. However, as Churchill-Davidson has said, "The simple observation of post-tetanic facilitation alone is not enough. It is only at a late stage, when these are very marked, that anticholinesterase therapy will be of any benefit. The judgment of this stage is based on an assessment of the degree of post-tetanic facilitation. If this is very marked and denotes vigorous muscle activity, then anti-cholinesterase therapy will improve neuromuscular transmission." 16

It is important to note that neostigmine administration will depress the cholinesterase activity, and thus give false abnormal readings for pseudocholinesterase levels-dibucaine numbers and fluoride number. Consequently blood should be drawn for investigative purposes before neostigmine or edrophonium are given.

Whole blood or plasma was used early in therapy of prolonged apnoea. A unit of whole blood raises pseudocholinesterase by 5 to $10 \mathrm{McArdle}$ Units. ${ }^{1}$ This may be of value in the quantitative deficiencies, but it is less likely to be of value in the qualitative, atypical homozygous deficiency.

Any apnoea of more than 15 minutes' duration, following a single dose of succinylcholine and in the absence of other factors, should be considered as a case of inherited pseudocholinesterase abnormality until biochemically proven otherwise. The patient should be investigated, and if abnormality is found, his family should also be investigated. Where abnormality is found, the patient, his family, and the family physician should be warned of the hazard involved.

During the past year eight cases in which patients exhibited an abnormal reaction to succinylcholine have been investigated in Edmonton (Table II). In all of them with the exception of patient 4 , the dose of succinylcholine was from 30 to $60 \mathrm{mg}$. In case 4 a 0.1 per cent succinylcholine drip was used for relaxation during the surgical procedure, and a total dose of $400 \mathrm{mg}$. of succinylcholine was used. This particular patient arrived in the operating room almost moribund with a bleeding peptic ulcer. At the termination of the procedure, blood gas studies showed him to be markedly acidotic and hypercarbic. Even when this was corrected with increased ventilation and sodium bicarbonate, he continued to suffer respiratory insufficiency necessitating controlled and then assisted respiration for eight hours. Subsequent biochemical investigation revealed a pseudocholinesterase level of 42 and a normal dibucaine number of 76 . In patient 1 , there were two complicating factors: first, the patient received $500 \mathrm{mg}$. of procaine subcutaneously along the suture line at the beginning of the surgical procedure. Procaine is hydrolysed by pseudocholinesterase preferentially to succinylcholine. ${ }^{22}$ This patient was subsequently found to have extensive recurrence of carcinoma of the cervix, and this may also have been a factor.

It should be noted that in all patients except patient 6, the cholinesterase activity was depressed. It is interesting to consider which patients have a low but normal type of pseudocholinesterase and which have a low activity due to a genetically different cholinesterase. Examination of the dibucaine number reveals that patients 2,3 , and 5 are probably atypical homozygotes $E_{1}{ }^{a} E_{1}{ }^{\mathrm{a}}$, while patients 6,7 , and 8 are probably heterozygotes of $E_{1}{ }^{a} E_{1}{ }^{a}$ genotype. Patients 1 and 4 are examples of what may be called clinically low, but normal cholinesterase, a 
TABLE II

Cases of Pseudocholinestrase Deficiency

\begin{tabular}{|c|c|c|c|c|c|c|c|c|}
\hline $\begin{array}{l}\text { Patient } \\
\text { no. }\end{array}$ & Age & Sex & Procedure & $\begin{array}{c}\text { Apnoea } \\
\text { (in hours) }\end{array}$ & $\begin{array}{c}\text { Pseudo- } \\
\text { cholin- } \\
\text { esterase } \\
\text { level } \\
(80-250)\end{array}$ & $\underset{\text { (over 75) }}{\text { D.N. }}$ & $\underset{\text { (over 60) }}{\text { F.N. }}$ & $\begin{array}{l}\text { Probable } \\
\text { P.C.E. } \\
\text { defect }\end{array}$ \\
\hline 1 & 57 & F. & discectomy & 10 & 73 & 70 & - & quantitative \\
\hline 2 & 28 & F. & nephrectomy & 2 & 19 & 16 & 14 & $\begin{array}{l}\text { atypical } \\
\text { homozygote }\end{array}$ \\
\hline 3 & 68 & F. & bronchoscopy & $3 \frac{3}{4}$ & 15 & 14 & - & $\begin{array}{l}\text { atypical } \\
\text { homozygote }\end{array}$ \\
\hline 4 & 72 & M. & hemigastrectomy & 6 & 42 & 76 & - & quantitative \\
\hline \multirow[t]{2}{*}{5} & 7 & $\mathrm{~F}$ & $T$ and $A$ & 3 & 38 & 15 & 9 & \multirow{2}{*}{$\begin{array}{l}\text { atypical } \\
\text { homozygote }\end{array}$} \\
\hline & $\begin{array}{l}\text { fath } \\
\text { mot }\end{array}$ & $\begin{array}{l}\text { her } \\
\text { ther }\end{array}$ & & & $\begin{array}{l}94 \\
61\end{array}$ & $\begin{array}{l}85 \\
65\end{array}$ & $\begin{array}{l}42 \\
39\end{array}$ & \\
\hline 6 & $\begin{array}{l}27 \\
\text { mot } \\
\text { brot }\end{array}$ & $\begin{array}{l}\text { F. } \\
\text { ther } \\
\text { ther }\end{array}$ & appendectomy & 1 & $\begin{array}{r}80 \\
89 \\
113\end{array}$ & $\begin{array}{l}67 \\
67 \\
62\end{array}$ & $\begin{array}{l}44 \\
46 \\
40\end{array}$ & heterozygote \\
\hline 7 & 47 & M. & E.S.T. & 1 & 53 & 28 & 34 & heterozygote \\
\hline 8 & 37 & M. & E.S.T. & $\frac{1}{2}$ & 77 & 56 & 38 & heterozygote \\
\hline
\end{tabular}

situation frequently found in various disease states. Investigation of the family of patient 5 has revealed an interesting fact: the father has a normal cholinesterase and DN, as noted. Thus the daughter can no longer be considered as an abnormal homozygote $E_{1}{ }^{a} E_{1}$, but must be considered as the very rare $(1: 8000) E_{1}{ }^{a}$ $\mathrm{E}_{1} \mathrm{~B}$, a heterozygote including the silent gene. Such persons are reported to have a grossly prolonged apnoea, clinically identical to $\mathrm{E}_{1}{ }^{\mathrm{a}} \mathrm{E}_{1}{ }^{\mathrm{a}}$ atypical, abnormal homozygotes. Biochemical studies performed on the mother, father, and brother of patient 6 revealed abnormal DN and FN in the mother and one brother, indicative of familial defect of $E_{1}{ }^{u} E_{1}{ }^{a}$ genotype.

In patients 1,3 , and 5 it is probable that premature use of neostigmine served to prolong the state of respiratory paralysis. In patient 1 , edrophonium and neostigmine were given after the peripheral nerve stimulator suggested the presence of fade and post-tetanic facilitation. In retrospect the degree of post-tetanic facilitation was not marked enough and the stage of dual block had not been fully achieved, and thus neostigmine served to compound the problem.

Two of the patients in the series, numbers 3 and 5, experienced previous episodes of prolonged succinylcholine apnoea. In both cases the patients were aware that they had had some difficulty during anaesthesia, but they were not aware of the details. Patients discovered with pseudocholinesterase defects should be warned to use Medic Alert Discs, or should be given warning cards for presentation to attending anaesthetists and surgeons.

\section{SUMMARY}

Pseudocholinesterase is essential for the rapid breakdown of succinylcholine. If pseudocholinesterase is quantitatively or qualitatively deficient, prolonged apnoea 
may result after administration of succinylcholine. Normal pseudocholinesterase activity is dependent upon allelic genes $E_{1} \mathbf{u}$. There now appear to be two atypical variant alleles and a silent allele. In anaesthetic practice the homozygous atypical pseudocholinesterase variants may be expected to be encountered with a frequency of about 1:3000.

The cornerstone of treatment of prolonged succinylcholine apnoea is adequate ventilation with maintenance of physiological levels of $\mathrm{pH}, \mathbf{P}_{\mathrm{CO}_{2}}$, and bicarbonate, and avoidance of hypoxia.

Patients experiencing prolonged apnoea should be biochemically investigated. Knowledge of a low pseudocholinesterase level will certainly be of interest. However, as is evident from the cases described here, this by itself will not reveal whether low activity is due to a low but normal type of enzyme, or to a genetic mutant. As certain drugs and illnesses may produce a low enzyme level, and such causes may only be temporary, it is of more than academic interest to determine the nature of the defect. If it is of genetic origin, it is a permanent defect and such persons should receive a warning card to alert physicians regarding this biochemical abnormality.

\section{RÉsuMǵ}

La pseudocholinestérase est essentielle au métabolisme rapide de la succinylcholine. En cas de déficit qualitatif ou quantitatif de la pseudocholinestérase, l'administration de succinylcholine peut entraîner une apnée prolongée. L'activité normale de la pseudocholinestérase dépend des gènes alléliques $\mathbf{E}_{1}{ }^{2}$. Actuellement, il y a deux sortes d'enzymes qui peuvent être identifiées par une diminution de susceptibilité a l'inhibition par la dibucaine et le fluorure. Ces formes mutantes sont désignées par $\mathrm{E}_{1}{ }^{\mathrm{a}}$ dans le cas de l'enzyme résistant à la dibucaïne, et $\mathrm{E}_{1}{ }^{\mathrm{t}}$ dans le cas de l'enzyme résistant au fluorure. Il existe aussi un gène silencieux désigné par $\mathrm{E}_{1}{ }^{8}$ et caractérisé par une absence complète d'activité.

La pierre angulaire du traitement des apnées prolongées après la succinylcholine demeure une ventilation adéquate avec le maintien de taux physiologiques du $\mathrm{pH}$, de la $\mathrm{P}_{\mathrm{OO}_{2}}$ et des bicarbonates.

Il faut étudier attentivement les malades qui présentent des apnées prolongées. Si les pseudocholinestérases sont diminuées en quantité, il faut étudier les familles du malade. Tous les individus chez qui on dépiste un trouble des pseudocholinestérases devraient porter une carte ou un disque d'avertissement.

\section{ACKNOWLEDGMENTS}

We would like to express our thanks to these anesthetists whose knowledge of this problem caused blood samples to be taken: Drs. D. F. Cameron, H. J. de Jongh, C. D. Elton, W. H. Graham, G. T. Moonie, R. T. Williams. Gratitude is also due to all concerned with the collection of samples from the patients' relatives.

\section{REFERENCES}

1. Lefrmann, H. \& Lmberc, J. The Cholinesterases. Modern Trends in Anaesthesia. 2 (1962).

2. KrTz, Rickiand J. The Chemistry of Anticholinesterase Activity. Acta Anaesth. Scandinav. 8: $197(1964)$. 
3. Svansmark, O. Molecular Properties of Cholinesterases. Acta Physiol. Scandinav. 64, Supp. 245: 39 (1965).

4. Doenicke, A.; Gurtner, T.; Kreutzeerc, G.; Remes, I.; Speiss, W.; \& Steinbereithner, K. Serum Cholinesterase Anenzymia: Report of a Case Confirmed by Enzyme-Histochemical Examination of Liver-Biopsy Specimen. Acta Anaesth. Scandinav. 7: 59 (1963).

5. Lmber.L, J.; LemmanN, H.; \& SILr, E. A Silent Pseudocholinesterase Gene. Nature (London). 193: 561 (1962).

6. Hodgkn, W. E.; Grbletr, E. R.; Levine, H.; Bauen, W.; \& Motulsky, A. G. Complete Pseudocholinesterase Deficiency: Genetic and Immunologic Characterization. J. Clin. Invest. 44: 486 (1965).

7. Love, S. H. S. Correspondence: Prolonged Apnoea Following Scoline. Anaesthesia. 7 : 113 (1952).

8. Harper, J. Kennedy. Correspondence: Prolonged Respiratory Paralysis after Succinylcholine. Brit. Med. J. I: 866 (1952).

9. Lancton-Hewer, C. Prolonged Respiratory Paralysis after Succinylcholine. Brit. Med. J. 1: 971 (1952).

10. Evans, F. T.; Gray, P. W. S.; Lemanan, H.; \& Sirk, E. Sensitivity to Succinylcholine, in Relation to Serum Cholinesterase. Lancet. 262: 1229 (1952).

11. LemmanN, H. The Familial Incidence of Low Pseudocholinesterase Level. Lancet. 271 : 124 (1956).

12. KaLow, W. \& Genest, K. Method of Detection of Atypical Forms of Human Cholinesterase: Determination of Dibucaine Numbers. Can. J. Biochem. 35: 339 (1957).

13. Harris, H. \& Wrutrakor, M. Differential Inhibition of Human Serum Cholinesterase with Fluoride: Recognition of Two New Phenotypes. Nature (London). 196: 496 (1961).

14. Kalow, W. \& Stamon, N. On Distribution and Inheritance of Atypical Forms of Human Serum Cholinesterase as Indicated by Dibucaine Numbers. Can. J. Biochem. 35: 1305 (1957).

15. Churchill-Davmson, H. C. The Causes and Treatment of Prolonged Apnea. Anesthesiology. 20: 535 (1959).

16. Cruurchuld-Davioson, H. C. \& Wise, R. P. Correspondence: Mismanagement of Suxamethonium Apnoea. Brit. J. Anaesth. 35: 506 (1963).

17. - Prevention, Diagnosis, and Treatment of Prolonged Apnoea. Brit. J. Anaesth. 32 : 384 (1960).

18. Vickens, M. D. The Cholinesterases and Their Significance to the Anaesthetist using Muscle Relaxants. Brit. J. Anaesth. 35: 528 (1963).

19. Kalow, W. The Distribution, Destruction and Elimination of Muscle Relaxants. Anesthesiology. 20: 505 (1959).

20. Churcimli-Davmson, H. C.; Cerristie, T. H.; \& Wise, R. P. Dual Neuromuscular Block in Man. Anesthesiology. 21: 155 (1961).

21. Crumchill-Davioson, H. C. Muscle Relaxants. Recent Advances in Anaesthesia and Analgesia. 9th ed. (1963).

22. Foldes, F. F.; MaNali, P. G.; Davis, D. L.; Ellis, C. H.; \& WNUCK, A. L. Substrate Competition between Procaine and Succinylcholine Diodide for Plasma Cholinesterase. Science. 117: 383 ( 1953). 